\title{
MAKALAH \\ PERMASALAHAN PENANGANAN KORUPSI \\ DAN SOLUSINYA
}

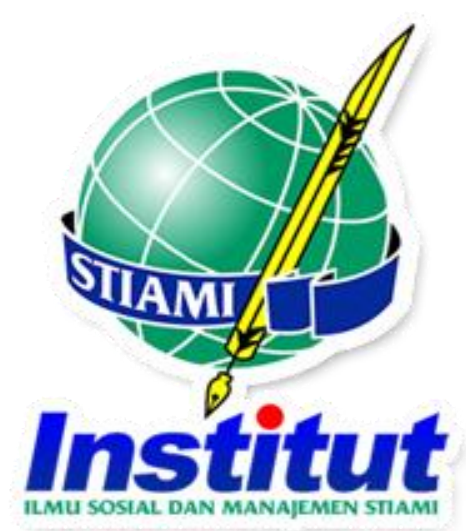

Disusun oleh :

GOMGOM DANIEL PARDOMUAN (BC191110041)

HEDDY JUANDA (BC191120013)

HEIN PRIMADA ENDARVIN (BC191110253)

Dosen : Dr. Ir. A.H Rahardian, M.Si

TEORI ADMINISTRASI PUBLIK

\author{
PROGRAM PASCA SARJANA \\ MAGISTER ADMINISTRASI PUBLIK \\ INSTITUT ILMU SOSIAL DAN MANAJEMEN STIAMI JAKARTA \\ TAHUN 2019
}




\section{KATA PENGANTAR}

Kami panjatkan puji syukur kehadirat-Nya yang telah melimpahkan rahmat, hidayah, serta inayah-Nya kepada kami sehingga kami bisa menyelesaikan makalah dengan judul "Permasalahan Penanganan Korupsi dan Solusinya".

Penulisan makalah dilakukan sebagai bagian dari tugas mata kuliah Teori Administrasi Publik di Program Pasca Sarjana Institut IImu Sosial dan Manajemen STIAMI (Institut STIAMI) bidang studi Administrasi Publik.

Makalah ini sudah kami susun dengan maksimal dan berkat kerjasama kelompok hingga bisa memperlancar pembuatan makalah ini.

Terlepas dari segala hal tersebut, Kami sadar sepenuhnya bahwa masih ada kekurangan baik dari segi susunan kalimat maupun tata bahasanya. Oleh karenanya kami dengan lapang dada menerima segala saran dan kritik agar kami dapat memperbaiki makalah ilmiah ini.

Akhir kata kami berharap semoga makalah ilmiah bisa memberikan manfaat maupun inspirasi untuk pembaca.

Jakarta, 31 Oktober 2019

Penyusun

Kelompok IV 


\section{DAFTAR ISI}

Kata Pengantar

Daftar Isi

BAB I

PENDAHULUAN

1. Latar Belakang 1

2. Ruang Lingkup Penulisan 8

3. Tujuan dan Manfaat Penulisan

BAB II

PERMASALAHAN

9

BAB III

SOLUSI (PEMECAHAN MASALAH)

BAB IV

PENUTUP (KESIMPULAN)

18

DAFTAR PUSTAKA

20 


\section{BAB I}

\section{PENDAHULUAN}

\section{A. LATAR BELAKANG MASALAH}

Indonesia merupakan Negara yang berdasarkan atas UUD 1945 dan Pancasila sebagai landasan falsafah Negara. Indonesia terdiri dari berbagai macam Agama yaitu Hindu, Budha, Kristen, Katholik, Islam dan Konghuchu sehingga setiap orang kebanyakan menilai orang dari segi sosial dan Agamanya. Pada masa ORLA dan ORBA penduduk Indonesia dikatakan sebagai penduduk yang bersifat ketimur-timuran karena sifatnya memang seperti orang-orang timur, maksudnya adalah sikap orang Indonesia pada saat itu bersikap sopan, santun, baik, ramah tamah dan jujur serta rasa sosialis yang tinggi. Tapi, pada awal era Reformasi sekitar tahun 2000-an penduduk Indonesia seketika berubah tapi bukan tidak melalui proses. Penduduk Indonesia telah terkena demonstration effect sehingga sebutan Indonesia sebagai Negara yang ketimur-timuran kini berubah menjadi Negara yang kebarat-baratan. Disebut Negara kebarat-baratan karena sikap moral dari pada penduduk Indonesia ini sudah mulai menurun dan ini termasuk sebagai salah satu permasalahaan sosial yang akan menyebabkan generasi muda sebagai generasi penerus mempunyai watak yang tidak baik, jika seperti itu maka kelanjutan dari pada Negara ini tidak akan bisa dibayangkan, betapa koprol nya nanti Negara ini jika dipimpin oleh pemimpin yang mempunyai watak dan moral yang kurang baik. Terlepas dari hal itu, nampaknya kini sudah ada hasilnya, dari mulai ORBA sampai Era Reformasi Pancasila yang bersifat demokratis seperti saat ini Indonesia sudah menerima hasilnya berupa pemerintahan yang koprol. Koprol dalam artian adalah para pemimpin dan ahli politik saling membenarkan persepsi sendiri dan mementingkan diri sendiri atau golongan sehingga rakyat kecil menjadi bingung dan terjadi KKN (Korupsi, Kolusi dan Nepotisme) yang semakin lama semakin marak dan semakin sulit untuk menumpasnya. Permasalahan ini memang bukan merupakan masalah yang baru, tapi sungguh sangat berbahaya bagi kelangsungan Negara ini, jika pemerintah dan para ahli politik 
saling bertentangan dalam persepsi mereka serta rasa egois untuk balik modal dalam kampanye yang dilakukan dan bukan semata-mata karena rakyat, sikap ini sangat amat bahaya sekali. Penyakit ini jika penulis samakan dalam penyakit manusia adalah sama halnya dengan penyakit HIV/AIDS yang karakteristik dari penyakit ini adalah gejala yang terjadi akan terasa setelah terkena selama maksimal 2 sampai 5 tahun yang melemahkan sistem kekebalan tubuh. Begitupun dengan penyakit Negara kita saat ini yaitu Korupsi, Kolusi, dan Nepotisme yang dampaknya akan kelihatan dalam selang waktu yang cukup lama. Bahkan Singapura pernah mengecap Indonesia sebagai the envelope country, jika diterjemahkan secara bebas artinya adalah sebuah Negara Amplop. Menurut penulis wajar Singapura mengecap Indonesia dengan sebutan itu dan seharusnya para Aparatur Negara tanpa terkecuali seharusnya berkaca dari ucapan itu dan bukan malah menuntut Singapura. Mengapa demikian?, jelas karena fakta yang ada di Indonesia saat ini adalah segala hal bisa dibeli mulai dari hukum, lisensi, tender, Wartawan, Hakim, Jaksa, petugas pajak dan dari lembaga Independen sekalipun bisa dibeli. Title atau julukan sebagai Negara terkorup tentunya sangat memanaskan telinga untuk didengar karena pasalnya Indonesia telah kalah dengan China, karena China kini sudah bisa untuk memperbaiki diri. Bahkan China mengambil langkah yang tegas dengan menghukum mati bagi yang melakukan tindak pidana korupsi atau penyalahgunaan kekuasaan. Jika terdapat pertanyaan, mengapa Indonesia tidak melakukan tindakan seperti itu?, jawabannya adalah tentu saja Indonesia tidak akan mengambil tindakan setegas itu karena merupakan pelanggaran Hak Azasi Manusia dan menurut Dr. Iyus Akhmad Haris, M.Pd,. menjelaskan bahwa permasalahan sosial yang terjadi di lain daerah walaupun pokok permasalahannya sama tapi belum tentu solusinya sama. Lantas, apa yang harus dilakukan pemerintah ? pertanyaan ini menjadi tanda tanya besar bagi Indonesia karena sampai saat ini pun Indonesia belum mampu menuntaskan permasalahan korupsi ini, seperti contoh kasus Bank Century. Masalah korupsi memang merupakan masalah yang besar dan menarik sebagai persoalan hukum yang menyangkut jenis kejahatan yang rumit penanggulangannya, karena korupsi mengandung aspek yang majemuk dalam kaitannya dengan (konteks) politik, ekonomi, dan sosial-budaya. 
Berbagai upaya pemberantasan sejak dulu ternyata tidak mampu mengikis habis kejahatan korupsi. Karena dalam Masalah pembuktian dalam tindak pidana korupsi memang merupakan masalah yang rumit, karena pelaku tindak pidana korupsi ini melakukan kejahatannya dengan rapi. Sulitnya pembuktian dalam perkara korupsi ini merupakan tantangan bagi para aparat penegak hukum untuk tetap konsisten dengan penuh rasa tanggung jawab. Jika mantan presiden Alm. Presiden Abdurrahman Wahid menyatakan cara pemberantasan korupsi adalah dengan cara pembuktian terbalik terhadap tindak pidana korupsi.

Korupsi bukan hal yang baru bagi bangsa Indonesia. Tanpa disadari, korupsi muncul dari kebiasaan yang dianggap lumrah dan wajar oleh masyarakat umum. Seperti memberi hadiah kepada pejabat/pegawai Negeri atau keluarganya sebagai imbal jasa sebuah pelayanan (KPK, 2006: 1).

Korupsi telah dianggap sebagai hal yang biasa, dengan dalih "sudah sesuai prosedur". Koruptor tidak lagi memiliki rasa malu dan takut, sebaliknya memamerkan hasil korupsinya secara demonstratif.Politisi tidak lagi mengabdi kepada konstituennya. Partai Politik bukannya dijadikan alat untuk memperjuangkan kepentingan rakyat banyak, melainkan menjadi ajang untuk mengeruk harta dan ambisi pribadi. Padahal tindak pidana korupsi merupakan masalah yang sangat serius, karena tindak pidana korupsi dapat membahayakan stabilitas dan keamanan Negara dan masyarakat, membahayakan pembangunan sosial, politik dan ekonomi masyarakat, bahkan dapat pula merusak Nilai-nilai Demokrasi serta moralitas bangsa karena dapat berdampak membudayanya tindak pidana korupsi tersebut. Sehingga harus disadari meningkatnya tindak pidana korupsi yang tidak terkendali akan membawa dampak yang tidak hanya sebatas kerugian Negara dan perekonomian Nasional tetapi juga pada kehidupan berbangsa dan bernegara. Perbuatan tindak pidana korupsi merupakan pelanggaran terhadap hak-hak sosial dan hak hak ekonomi masyarakat, sehingga tindak pidana korupsi tidak dapat lagi digolongkan sebagai kejahatan biasa (ordinary crimes) melainkan telah menjadi kejahatan luar biasa (extra-ordinary crimes). Sehingga dalam upaya pemberantasannya tidak lagi dapat dilakukan "secara biasa",tetapi dibutuhkan "cara-cara yang luar biasa" (extra-ordinary crimes). 
Dalam arti yang luas, korupsi atau korupsi politis adalah penyalahgunaan jabatan resmi untuk keuntungan pribadi. Semua bentuk pemerintah pemerintahan rentan korupsi dalam prakteknya. Beratnya korupsi berbedabeda dari yang paling ringan dalam bentuk penggunaan pengaruh dan dukungan untuk memberi dan menerima pertolongan, sampai dengan korupsi berat yang diresmikan, dan sebagainya. Titik ujung korupsi adalah kleptokrasi, yang arti harfiahnya pemerintahan oleh para pencuri, dimana pura-pura bertindak jujur pun tidak ada sama sekali.

Korupsi yang muncul di bidang politik dan birokrasi bisa berbentuk sepele atau berat, terorganisasi atau tidak. Walau korupsi sering memudahkan kegiatan kriminal seperti penjualan narkotika, pencucian uang dan prostitusi, korupsi itu sendiri tidak terbatas dalam hal-hal ini saja. Untuk mempelajari masalah ini dan membuat solusinya, sangat penting untuk membedakan antara korupsi dan kriminalitas kejahatan. Tergantung dari negaranya atau wilayah hukumnya, ada perbedaan antara yang dianggap korupsi atau tidak. Sebagai contoh, pendanaan Partai Politik ada yang legal di satu tempat namun ada juga yang tidak legal di tempat lain.

Korupsi ternyata dilakukan oleh orang yang berpendidikan tinggi. Rasanya sungguh tidak pantas, seseorang yang berpendidikan melakukan hal yang seharusnya tidak boleh dilakukan. Korupsi tidak boleh dilakukan karena akan menimbulkan kerugian bagi pihak lain dan hanya memberikan keuntungan kepada pihak yang korupsi atau biasa disebut dengan koruptor. Faktanya korupsi dilakukan oleh orang yang mempunyai kekuasaan. Misalnya dalam pemerintahan, mereka menyalahgunakan kekuasaan hanya untuk kepentingan pribadi. Bisa dilihat dari kasus korupsi wisma atlet yang menjerat Angelina Sondakh, yang merupakan anggota Dewan Perwakilan Rakyat. Sebagai wakil rakyat seharusnya mengemban baik-baik tugas dan amanah yang telah dipercayakan oleh rakyat. Namun pada kenyataannya mereka mementingkan keinginan mereka sendiri, melupakan tanggung jawab mereka sebagai wakil rakyat.

Dengan maraknya korupsi yang ada di Indonesia, maka dibentuklah Komisi Pemberantasan Korupsi (KPK). Komisi Pemberantasan Korupsi (KPK) adalah lembaga yang dibentuk dengan tujuan meningkatkan daya guna dan hasil guna terhadap upaya pemberantasan tindak pidana korupsi. Selain itu 
KPK juga merupakan lembaga yang independen dan bebas dari pengaruh dalam melaksanakan tugasnya, seperti yang tercantum pada Pasal 3 UndangUndang Republik Indonesia Nomor 30 Tahun 2002. Mereka para koruptor bisa dikatakan pemberani, karena tidak takut dengan sanksi yang akan mereka dapatkan. Sanksi dibuat agar memberikan efek jera dan tidak akan mengulangi korupsi lagi. Dalam Undang-Undang Republik Indonesia Nomor 20 Tahun 2001 telah dijelaskan mengenai sanksi-sanksi dalam berbagai macam tindak korupsi. Pada kenyataannya masih saja banyak ditemukan kasus korupsi, seakan-akan mereka tidak takut dengan hukuman atau sanksi yang akan mereka dapat setelah terbukti sebagai koruptor nantinya. Hukuman dan sanksi yang telah dirumuskan untuk para pelaku korupsi rasanya hanya dianggap sebagai angin lalu saja. Karena hal tersebut muncul gagasan mengenai hukuman mati bagi koruptor untuk memberikan efek jera, namun gagasan tersebut menimbulkan pro dan kontra. Kondisi Negara yang menderita kerugian akibat kasus korupsi sangat memprihatinkan. Ketika upaya pemberantasan korupsi dengan membebankan sanksi yang berat kepada koruptor belum juga mampu membuat korupsi lenyap, maka upaya pencegahan mulai dipertimbangkan. Karena mencegah lebih baik dari pada mengobati. Selain itu bila hanya menekankan pada hukuman yang diberikan pada koruptor tidak akan ada habisnya. Kasus korupsi akan selalu muncul, dari generasi ke generasi.

Korupsi sangat berkaitan dengan kesadaran, kesadaran akan hukum tiaptiap orang tentu saja berbeda. Tetapi bila dilihat dari banyaknya kasus korupsi yang ada, bisa disimpulkan bahwa kesadaran hukum warga Indonesia cukup rendah. Perlu adanya penanaman kesadaran serta nilai-nilai positif lain sejak dini, agar generasi muda nantinya akan mampu membawa bangsa Indonesia menjadi lebih baik.

Banyak faktor pendorong terjadinya korupsi di Indonesia, yakni diantaranya : Konsentrasi kekuasan dipengambil keputusan yang tidak bertanggung jawab langsung kepada rakyat, seperti yang sering terlihat di rezim-rezim yang bukan demokratis; Gaji yang masih rendah; kurang sempurnanya peraturan perundang-undangan, administrasi yang lamban; Sikap mental para pegawai yang ingin cepat kaya dengan cara yang haram, tidak ada kesadaran bernegara, tidak ada pengetahuan pada bidang pekerjaan 
yang dilakukan oleh pejabat pemerintah; Kurangnya transparansi di pengambilan keputusan pemerintah; Kampanye-kampanye politik yang mahal, dengan pengeluaran lebih besar dari pendanaan politik yang normal; Proyek yang melibatkan uang rakyat dalam jumlah besar.; Lingkungan tertutup yang mementingkan diri sendiri dan jaringan "teman lama"; Lemahnya ketertiban hukum; Lemahnya profesi hukum; Gaji pegawai pemerintah yang sangat kecil; Rakyat yang apatis, masa bodoh, tidak tertarik, atau mudah dibohongi; Ketidakadaannya kontrol yang cukup untuk mencegah penyuapan.

Korupsi memberikan dampak buruk bagi Negara. Korupsi menunjukan tantangan serius terhadap pembangunan. Di dalam dunia politik, korupsi mempersulit demokrasi dan tata pemerintahan yang baik (good governance) dengan cara menghancurkan proses formal. Korupsi di pemilihan umum dan di badan legislatif mengurangi akuntabilitas dan perwakilan di pembentukan kebijaksanaan; korupsi di sistem pengadilan menghentikan ketertiban hukum; dan korupsi di pemerintahan publik menghasilkan ketidak-seimbangan dalam pelayanan masyarakat. Secara umum, korupsi mengkikis kemampuan institusi dari pemerintah, karena pengabaian prosedur, penyedotan sumber daya, dan pejabat diangkat atau dinaikan jabatan bukan karena prestasi. Pada saat yang bersamaan, korupsi mempersulit legitimasi pemerintahan dan nilai demokrasi seperti kepercayaan dan toleransi.

Korupsi juga mempersulit pembangunan ekonomi dengan membuat distorsi dan ketidakefisienan yang tinggi. Dalam sektor privat, korupsi meningkatkan ongkos niaga karena kerugian dari pembayaran illegal, ongkos manajemen dalam negosiasi dengan pejabat korup dan risiko pembatalan perjanjian atau karena penyelidikan.

Walaupun ada yang menyatakan bahwa korupsi mengurangi ongkos (niaga) dengan mempermudah birokrasi, konsensus yang baru muncul berkesimpulan bahwa ketersediaan sogokan menyebabkan pejabat untuk membuat aturan-aturan baru dan hambatan baru. Dimana korupsi menyebabkan inflasi ongkos niaga, korupsi juga mengacaukan "lapangan perniagaan". Perusahaan yang memiliki koneksi dilindungi dari persaingan dan sebagai hasilnya mempertahankan perusahaan-perusahaan yang tidak efisien. 
Korupsi menimbulkan distorsi (kekacauan) di dalam sektor publik dengan mengalihkan investasi publik ke proyek-proyek masyarakat yang mana sogokan dan upah tersedia lebih banyak. Pejabat mungkin menambah kompleksitas proyek masyarakat untuk menyembunyikan praktek korupsi, yang akhirnya menghasilkan lebih banyak kekacauan. Korupsi juga mengurangi pemenuhan syarat-syarat keamanan bangunan, lingkungan hidup, atau aturanaturan lain. Korupsi juga mengurangi kualitas pelayanan pemerintahan dan infrastruktur dan menambahkan tekanan-tekanan terhadap anggaran pemerintah.

Indonesia, sebagai salah satu Negara yang telah merasakan dampak dari tindakan korupsi, terus berupaya secara konkrit, dimulai dari pembenahan aspek hukum, yang sampai saat ini telah memiliki banyak sekali rambu-rambu berupa peraturan - peraturan, antara lain Tap MPR XI tahun 1980, kemudian tidak kurang dari 10 UU anti korupsi, diantaranya UU Nomor 20 Tahun 2001 tentang perubahan UU Nomor 31 Tahun 1999 tentang Pemberantasan Tindak Pidana Korupsi, kemudian yang paling monumental dan strategis, Indonesia memiliki UU Nomor 30 Tahun 2002, yang menjadi dasar hukum pendirian Komisi Pemberantasan Korupsi (KPK). Dengan demikian pemberantasan dan pencegahan korupsi telah menjadi gerakan Nasional. Seharusnya dengan sederet peraturan dan partisipasi masyarakat tersebut akan semakin menjauhkan sikap dan pikiran kita dari tindak korupsi.

Masyarakat Indonesia bahkan dunia terus menyoroti upaya Indonesia dalam mencegah dan memberantas korupsi. Masyarakat dan bangsa Indonesia harus mengakui, bahwa hal tersebut merupakan sebuah prestasi, dan juga harus jujur mengatakan, bahwa prestasi tersebut, tidak terlepas dari kiprah KPK sebagai lokomotif pemberantasan dan pencegahan korupsi di Indonesia.

Berbagai upaya pemberantasan korupsi, pada umumnya masyarakat masih dinilai belum menggambarkan upaya sungguh-sungguh dari pemerintah dalam pemberantasan korupsi di Indonesia. Berbagai sorotan kritis dari publik menjadi ukuran bahwa masih belum lancarnya laju pemberantasan korupsi di Indonesia. Masyarakat menduga masih ada praktek tebang pilih dalam pemberantasan korupsi di Indonesia. 


\section{Ruang Lingkup Penulisan}

Bertolak dari latar belakang diatas, maka yang menjadi ruang lingkup penulisan yang akan dibahas yaitu persoalan korupsi, dampak dan solusinya.

\section{Tujuan dan Manfaat Penulisan}

Tujuan dan manfaat penulisan makalah ini adalah :

a. Untuk mengetahui persoalan korupsi yang timbul di Negara ini serta dampaknya bagi Negara dan masyarakat.

b. Untuk mengetahui faktor-faktor penyebab timbulnya perilaku korup di kalangan pelaku birokrasi dan kalangan usaha.

c. Hasil penulisan ini diharapkan dapat memberikan manfaat sebagai solusi pemecahan masalah dalam pemberantasan korupsi. 


\section{BAB II}

\section{PERMASALAHAN}

Korupsi dapat dipandang sebagai fenomena politik, fenomena sosial, fenomena budaya, fenomena ekonomi, dan sebagai fenomena pembangunan. Karena itu pula upaya penanganan korupsi harus dilakukan secara komprehensif melalui startegi atau pendekatan Negara/politik, pendekatan pembangunan, ekonomi, sosial dan budaya. Berdasarkan pengertian, korupsi di Indonesia dipahami sebagai perilaku pejabat dan atau organisasi (Negara) yang melakukan pelanggaran dan penyimpangan terhadap norma-norma atau peraturan-peraturan yang ada. Korupsi dipahami sebagai kejahatan Negara (state corruption). Korupsi terjadi karena monopoli kekuasaan, ditambah kewenangan bertindak, ditambah adanya kesempatan, dikurangi pertangungjawaban. Jika demikian, menjadi wajar bila korupsi sangat sulit untuk diberantas apalagi dicegah, karena korupsi merupakan salah satu karakter atau sifat negara, sehingga negara=Kekuasaan=Korupsi.

Sebagai suatu kejahatan luar biasa, korupsi memiliki banyak wajah. Dalam sektor produksi, korupsi ada dari hulu sampai hilir, dari anak-anak sekolah sampai presiden, dari konglomerat sampai tokoh Agama. Kwik Kian Gie, Ketua Bappenas, menyebut lebih dari 300 Triliun dana dari penggelapan pajak, kebocoran APBN, maupun penggelapan hasil sumber daya alam, menguap ke kantong para koruptor. Korupsi bisa diiringi dengan kolusi, membuat keputusan yang diambil oleh pejabat Negara menjadi titik optimal. Heboh privatisasi sejumlah BUMN, lahirnya perundang-undangan aneh semacam UU energi, juga RUU SDA, import gula dan beras dan sebagainya dituding banyak pihak kebijakan yang sangat kolutif karena di belakangnya ada motivasi korupsi. Bentuk korupsi terhadap uang Negara tidak hanya terhadap utang luar Negeri. Namun, juga utang domestik dalam bentuk obligasi rekap bank-bank sebesar 650 Triliun. Skandal BLBI yang tak kunjung usai setidaknya menunjukkan terjadinya korupsi tingkat tinggi di kalangan pejabat keuangan, konglomerat serta banker. 
Kasus yang masih belum cukup lama adalah skandal Bank Century pun telah menyebabkan uang lenyap, namun pelakunya tak ada yang ditangkap. Kasus korupsi BNI dengan nilai 1,7 Triliun yang ternyata kemudian juga diikuti dengan Bank plat merah yaitu BRI dalam kasus jual-beli quota haji di wilayah kewenangan Kementerian Agama dan kasus "tarif" untuk calon legislatif untuk nomor-nomor jadi yang bernilai hingga ratusan juta rupiah. Tidak hanya itu, korupsi pun terjadi di daerah-daerah setingkat provinsi dan kota. Dalam harian Jurnal Bogor di bulan Juni 2009 memberitakan bahwa sekitar 90 persen bantuan sosial (bansos) dari Pemerintah Provinsi Jawa Barat dipastikan diselewengkan. Menurut Kepala Kejaksaan tinggi (Kejati) Drs. H.M. Amari, SH. $\mathrm{MH}$, dari total dana yang disalurkan ke semua daerah di Jabar termasuk Bogor itu, hanya $10 \%$ saja yang sampai ke masyarakat. Sementara yang $90 \%$ nya tidak tersalurkan oleh penerima bansos, seperti pengurus politik, yayasan, panitia pembangunan rumah ibadah dan lembaga pendidikan. Kejadian yang sangat mencoreng lembaga pemerintahan adalah, kejadian penyelewengan atau penggelapan uang pajak oleh Gayus dan rekan-rekannya yang ber triliuntriliun besarnya dan hingga sampai saat ini kasus ini belum selesai juga. Tentu saja tindakan korupsi sangatlah merugikan berbagai pihak. Korupsi juga membuat semakin bertambahnya kesenjangan akibat buruknya distribusi kekayaan. Bila sekarang kesenjangan kaya dan miskin sudah demikian menjauh, maka korupsi juga makin melebarkan kesenjangan itu karena uang terdistribusi secara tidak sehat (tidak mengikuti kaedah-kaedah ekonomi sebagaimana mestinya). Koruptor makin kaya, dan yang miskin makin miskin. Akibatnya lainnya, karena uang gampang diperoleh, sikap konsumtif jadi terangsang. Tidak ada dorongan ke pola produktif, sehingga timbul in-efisiensi dalam pemanfaatan sumber daya ekonomi.

Maraknya korupsi di Indonesia disinyalir terjadi di semua bidang dan sektor pembangunan. Apalagi setelah ditetapkannya pelaksanaan otonomi daerah, berdasarkan Undang-Undang Nomor 22 Tahun 1999 tentang Pemerintahan Daerah yang diperbaharui dengan Undang-Undang Nomor 32 tahun 2004, disinyalir korupsi terjadi bukan hanya pada tingkat pusat tetapi juga pada tingkat daerah dan bahkan menembus ke tingkat pemerintahan yang paling kecil di daerah. 
Pemerintah Indonesia sebenarnya tidak tinggal diam dalam mengatasi praktek-praktek korupsi. Upaya pemerintah dilaksanakan melalui berbagai kebijakan berupa peraturan perundang-undangan dari yang tertinggi yaitu Undang-Undang Dasar 1945 sampai dengan Undang-Undang tentang Komisi Pemberantasan Tindak Pidana Korupsi. Selain itu, pemerintah juga membentuk komisi-komisi yang berhubungan langsung dengan pencegahan dan pemberantasan tindak pidana korupsi seperti Komisi Pemeriksa Kekayaan Penyelenggara Negara (KPKPN) dan Komisi Pemberantasan Korupsi (KPK). Upaya pencegahan praktek korupsi juga dilakukan di lingkungan eksekutif atau penyelenggara negara, dimana masing-masing instansi memiliki Internal Control Unit (unit pengawas dan pengendali dalam instansi) yang berupa Inspektorat. Fungsi Inspektorat mengawasi dan memeriksa penyelenggaraan kegiatan pembangunan di instansi masing-masing, terutama pengelolaan keuangan negara, agar kegiatan pembangunan berjalan secara efektif, efisien dan ekonomis sesuai sasaran. Di samping pengawasan internal, ada juga pengawasan dan pemeriksaan kegiatan pembangunan yang dilakukan oleh instansi eksternal yaitu Badan Pemeriksa Keuangan (BPK) dan Badan Pengawas Keuangan Pembangunan (BPKP). Selain lembaga internal dan eksternal, lembaga swadaya masyarakat (LSM) juga ikut berperan dalam melakukan pengawasan kegiatan pembangunan, terutama kasus-kasus korupsi yang dilakukan oleh penyelenggara negara. Beberapa LSM yang aktif dan gencar mengawasi dan melaporkan praktek korupsi yang dilakukan penyelenggara negara antara lain adalah Indonesian Corruption Watch (ICW), Government Watch (GOWA), dan Masyarakat Tranparansi Indonesia (MTI).

Dilihat dari upaya-upaya pemerintah dalam memberantas praktek korupsi di atas sepertinya sudah cukup memadai baik dilihat dari segi hukum dan peraturan perundang-undangan, komisi-komisi, lembaga pemeriksa baik internal maupun eksternal, bahkan keterlibatan LSM. Namun, kenyataannya praktek korupsi bukannya berkurang malah meningkat dari tahun ke tahun. Bahkan Indonesia kembali dinilai sebagai negara paling terkorup di Asia pada awal tahun 2004 dan 2005 berdasarkan hasil survei di kalangan para pengusaha dan pebisnis oleh lembaga konsultan Political and Economic Risk Consultancy (PERC). 
Hasil survei lembaga konsultan PERC yang berbasis di Hong Kong menyatakan bahwa Indonesia merupakan Negara yang paling korup di antara 12 Negara Asia. Predikat negara terkorup diberikan karena nilai Indonesia hampir menyentuh angka mutlak 10 dengan skor 9,25 (nilai 10 merupakan nilai tertinggi atau terkorup). Pada tahun 2005, Indonesia masih termasuk dalam tiga teratas negara terkorup di Asia. Peringkat negara terkorup setelah Indonesia, berdasarkan hasil survei yang dilakukan PERC, yaitu India $(8,9)$, Vietnam $(8,67)$, Thailand, Malaysia dan China berada pada posisi sejajar di peringkat keempat yang terbersih. Sebaliknya, negara yang terbersih tingkat korupsinya adalah Singapura $(0,5)$ disusul Jepang $(3,5)$, Hong Kong, Taiwan dan Korea Selatan. Rentang skor dari nol sampai 10, di mana skor nol adalah mewakili posisi terbaik, sedangkan skor 10 merupakan posisi skor terburuk. Indonesia berada pada peringkat teratas dalam IPK (Indeks Persepsi Korupsi) di kawasan Asia. Kenyataan pahit yang harus kita terima sebagai rakyat Indonesia. Apakah kita harus menerima IPK ini, dan apakah kita harus menerima kelakuan para pemimpin kita yang seharusnya mempunyai kepercayaan untuk membangun bangsa dan Negeri ini menjadi lebih baik dan bukan menjadi terpuruk dan hancur ?. Jika di tingkat Asia prestasi kita dalam korupsi bisa dibilang buruk, Begitu pula dengan Indeks Persepsi Korupsi (IPK) Indonesia tahun 2006 adalah 2,4 dan menempati urutan ke-130 dari 163 NLegara. Sebelumnya, pada tahun 2005 IPK Indonesia adalah 2,2 tahun 2004 $(2,0)$ serta tahun $2003(1,9)$. Hal ini menunjukkan bahwa penanganan kasus korupsi di Indonesia masih sangat lambat dan belum mampu membuat jera para koruptor. 


\section{BAB III}

\section{SOLUSI (PEMECAHAN MASALAH)}

Korupsi tidak dapat dibiarkan berjalan begitu saja kalau suatu Negara ingin mencapai tujuannya, karena kalau dibiarkan secara terus menerus, maka akan terbiasa dan menjadi subur dan akan menimbulkan sikap mental pejabat yang selalu mencari jalan pintas yang mudah dan menghalalkan segala cara (the end justifies the means). Untuk itu, korupsi perlu ditanggulangi secara tuntas dan bertanggung jawab. Ada beberapa upaya penanggulangan korupsi yang ditawarkan para ahli yang masing-masing memandang dari berbagai segi dan pandangan.

Menurut pendapat H. Ismail Susanto, terdapat enam langkah yang harus dilakukan agar korupsi tidak hilang dan tidak dilakukan oleh masyarakat. Didalam sebuah essay-nya yang dimuat di Harian Republika mengatakan bahwa berdasarkan kajian terhadap berbagai sumber, didapatkan sejumlah cara sebagaimana ditunjukkan oleh Syariat Islam.

Pertama, sistem penggajian yang layak. Aparat pemerintah harus bekerja dengan sebaik-baiknya. Dan itu sulit berjalan dengan baik apabila gaji mereka tidak mencukupi, karena para birokrat juga manusia biasa. Kedua, larangan menerima suap dan hadiah. Hadiah dan suap yang diberikan kepada aparatur pemerintah pasti mengandung maksud tertentu, karena buat apa seseorang memberikan sesuatu kalau tidak ada maksud tertentu. Ketiga, perhitungan kekayaan. Orang yang melakukan korupsi tentu kekayaannya akan bertambah dengan cepat. Meski tidak selalu orang yang cepat kaya itu melakukan tindakan korupsi. Bisa saja dia mendapatkan kekayaan itu dari warisan, keberhasilan bisnis atau dengan cara lain yang halal. Keempat, teladan pemimpin. Pemberantasan korupsi hanya akan bisa dilakukan jika para pemimpin, terlebih pemimpin tertinggi, dalam sebuah Negara bersih dari korupsi. Dengan takwa, seorang pemimpin melakukan tugasnya dangan penuh amanah. 
Karena dengan taqwa pula ia takut untuk melakukan penyimpangan, karena meski ia bisa melakukan kolusi dengan pejabat lain untuk menutup kejahatannya, Allah SWT pasti melihat semuanya dan di akhirat nanti pasti akan dimintai pertanggung jawaban. Kelima, hukuman yang setimpal. Pada dasarnya, orang akan takut menerima resiko yang akan mencelakakan dirinya, termasuk bila ditetapkan hukuman setimpal bagi para koruptor. Berfungsi sebagai pencegah, hukuman setimpal atas koruptor membuat orang jera dan kapok melakukan korupsi. Keenam, Pengawasan Masyarakat. Masyarakat dapat berperan menyuburkan atau menghilangkan korupsi. Dari point-point tersebut dapat dieksplisitkan bahwa pemberantasan korupsi harus melibatkan semua pilar masyarakat. Pilar masyarakat adalah manusia (individu), budaya (yaitu berupa persepsi baik pemikiran maupun perasaan kolektif), dan sistem aturan yang berlaku. Karena itu, korupsi akan lebih efektif diberantas bila pada tiga pilar tersebut dilakukan langkah-langkah yang terpadu. Bahwa ada individu yang memang bejat, ingin kaya secara instant, atau setidaknya dengan harta dengan jalan pintas, itu memang kenyataan di dunia ini. Tapi, individu yang baik sebenarnya banyak. Andaikan di dunia ini lebih banyak yang tidak baik, tentu kehidupan tidak bisa lagi berjalan dengan normal. Orang selalu dalam ketakutan karena tidak ingin ditipu, atau semangat untuk menipu. Kalau sudah begitu tidak ada lagi hubungan dengan manusia, baik berdagang maupun menikah.

Jadi kita harus meyakini bahwa sebagian besar individu pada dasarnya adalah baik, karena Allah telah meniupkan sifat-sifat agungnya dalam diri manusia sejak masih didalam rahim. Didalam surat Qs. 15- al hijr; 29, yang artinya, maka apabila Aku telah menyempurnakan kejadiannya dan telah meniupkan kedalamnya ruh (ciptaan)-ku, maka tunduk kamu kepadanya dengan bersujud. Dapat disimpulkan bahwa pada awalnya manusia semuanya memiliki sifat yang baik, akan tetapi sebagian orang yang menjadi koruptor itu tentu karena pengaruh eksternal yang telah mengaburkan sifat-sifat baik tersebut. Yang paling utama adalah pendidikan, kedua lingkungan dan ketiga media. Tiga hal ini akan membangun suatu budaya, yakni suatu persepsi kolektif dalam masyarakat, apakah suatu hal itu akan dianggap normal atau tidak. 
Pada masyarakat yang budaya "uang pelicin" sudah dianggap wajar, maka orang tidak akan lagi peka dan merasa itu adalah korupsi. Demikian juga budaya "titip saudara" agar lolos ujian sekolah atau dapat pekerjaan. Andaikata dua hal ini dicoba pada masyarakat yang memilki persepsi sebaliknya, bahwa uang pelicin itu haram, dan nepotisme itu awal kehancuran, tentu akan terjadi sasuatu yang berbeda. Budaya adalah sesuatu yang dapat dibentuk peran pendidikan sangat besar. Para guru itulah yang menanamkan nilai-nilai sejak dini. Tentu saja mereka pula yang berhak memberikan sikap keteladanan yang baik. Kalau sang guru sendiri dulu mendapatkan pekerjaan dengan menggunakan uang pelicin atau lulus ujian guru dengan mencontek, ya susah. Mereka merupakan bagian dari masalah dan bukan merupakan sebuah solusi. Budaya anti korupsi akan menghasilkan individuindividu anti-korupsi, yang akhirnya akan menjadi aktor-aktor pencegahan atau pemberantasan korupsi. Pada masyarakat yang sarat dengan korupsi, tentu saja sulit untuk mendapatkan individu-individu semacam ini. Namun dalam level mikro, seperti pada suatu sekolah, kantor atau suatu organisasi, budaya ini bisa ditumbuhkan melalui pendidikan, keteladanan pemimpin dan lewat kampanya yang massif, misalnya dengan pemasangan poster-poster yang akan mengingatkan orang akan dampak mengerikan dari korupsi, atau azab Allah yang dijanjikan pada koruptor. Namun juga strategi individual dan kultural terkadang masih belum cukup juga. Korupsi juga terjadi dengan adanya aturan-aturan main yang salah. Sebagai contoh; aturan biaya mutasi kendaraan yang lumayan tinggi (10\% harga kendaraan), membuat sebagian orang enggan untuk melakukan balik nama setelah membeli kendaraan bekas. Hasilnya, di beberapa daerah cukup sulit menemukan mobil dengan nama pemilik sebenarnya pada STNK. Ketika ada PNS untuk datang ke daerah itu dan akan menyewa mobil, yang ada hanyalah mobil seperti itu. Padahal di aturan sewa kendaraan dalam pekerjaan pemerintah, diwajibkan nama pemilik mobil seperti dalam KTP harus sama dalam nama STNK. Lalu solusinya apa? Solusi jangka pendeknya adalah bisa menggunakan fotocopy STNK palsu atau menyuap agar petugas kantor kas Negara dan auditor pura-pura tidak melihat. Cara yang lebih elegan adalah dengan membuat klausul tambahan pada aturan yang formal berlaku, yang kalau tetap dalam bentuk sekarang ini, akan menimbulkan akses yang rumit di lapangan. 
Perubahan aturan-aturan ini dapat berupa aturan sewanya atau aturan balik nama kendaraannya. Misalnya biayanya diturunkan, agar pemilik kendaraan tertarik untuk balik nama. Contoh lainnya adalah hubungan kerja yang kabur, sehingga tidak jelas apakah seorang direktur BUMN/BUMD itu perlu dibayar tinggi meskipun perusahaan merugi atau dia sebenarnya hanya perlu digaji secukupnya, sedang penghasilan yang tinggi tergantung prestasinya. Dari beberapa contoh diatas adalah contoh untuk merubah aturan dalam mencegah korupsi. Contoh yang lain adalah aturan yang dapat memberantas korupsi setelah terjadi. Perhitungan kekayaan pejabat setelah menjabat untuk dibandingkan dengan sebelumnya adalah salah satu ide yang baik. Kalau ada peningkatan yang tidak wajar dan tidak bisa dijelaskan, harta itu dapat disita untuk Negara, atau yang bersangkutan dipidana.

Caiden (dalam Soerjono, 1980) memberikan langkah-langkah untuk menanggulangi korupsi sebagai berikut :

1. Membenarkan transaksi yang dahulunya dilarang dengan menentukan sejumlah pembayaran tertentu.

2. Membuat struktur baru yang mendasarkan bagaimana keputusan dibuat.

3. Melakukan perubahan organisasi yang akan mempermudah masalah pengawasan dan pencegahan kekuasaan yang terpusat, rotasi penugasan, wewenang yang saling tindih organisasi yang sama, birokrasi yang saling bersaing, dan penunjukan instansi pengawas adalah saran-saran yang secara jelas diketemukan untuk mengurangi kesempatan korupsi.

Cara yang diperkenalkan oleh Caiden di atas membenarkan (legalized) tindakan yang semula dikategorikan kedalam korupsi menjadi tindakan yang legal dengan adanya pungutan resmi. Di lain pihak, celah-celah yang membuka untuk kesempatan korupsi harus segera ditutup, begitu halnya dengan struktur organisasi haruslah membantu kearah pencegahan korupsi, misalnya tanggung jawab pimpinan dalam pelaksanaan pengawasan melekat, dengan tidak lupa meningkatkan ancaman hukuman kepada pelaku-pelakunya. Selanjutnya, Myrdal (dalam Lubis, 1987) memberi saran penanggulangan korupsi yaitu agar pengaturan dan prosedur untuk keputusan-keputusan administratif yang menyangkut orang perorangan dan perusahaan lebih disederhanakan dan dipertegas, pengadakan pengawasan yang lebih keras, kebijaksanaan pribadi dalam menjalankan kekuasaan hendaknya dikurangi sejauh mungkin, gaji pegawai yang rendah harus dinaikkan dan kedudukan sosial ekonominya diperbaiki, lebih terjamin, satuan-satuan 
pengamanan termasuk Polisi harus diperkuat, hukum pidana dan hukum atas pejabat-pejabat yang korupsi dapat lebih cepat diambil. Orang-orang yang menyogok pejabat-pejabat harus ditindak pula. Persoalan korupsi beraneka ragam cara melihatnya, oleh karena itu cara pengkajiannya pun bermacam-macam pula. Korupsi tidak cukup ditinjau dari segi deduktif saja, melainkan perlu ditinjau dari segi induktifnya yaitu mulai melihat masalah praktisnya (practical problems), juga harus dilihat apa yang menyebabkan timbulnya korupsi. Kartono (1983) menyarankan penanggulangan korupsi sebagai berikut :

1. Adanya kesadaran rakyat untuk ikut memikul tanggung jawab guna melakukan partisipasi politik dan kontrol sosial dengan bersifat acuh tak acuh.

2. Menanamkan aspirasi Nasional yang positif, yaitu mengutamakan kepentingan Nasional.

3. Para pemimpin dan pejabat memberikan teladan, memberantas dan menindak korupsi.

4. Adanya sanksi dan kekuatan untuk menindak, memberantas dan menghukum tindak korupsi.

5. Reorganisasi dan rasionalisasi dari organisasi pemerintah, melalui penyederhanaan jumlah Kementerian beserta jawatan dibawahnya.

6. Adanya sistem penerimaan pegawai yang berdasarkan "achievement" dan bukan berdasarkan sistem "ascription".

7. Adanya kebutuhan Pegawai Negeri yang non-politik demi kelancaran administrasi pemerintah.

8. Menciptakan aparatur pemerintah yang jujur

9. Sistem budget dikelola oleh pejabat-pejabat yang mempunyai tanggung jawab etis tinggi, dibarengi sistem kontrol yang efisien.

10. Herregistrasi (pencatatan ulang) terhadap kekayaan perorangan yang mencolok dengan pengenaan pajak yang tinggi. 


\section{BAB IV}

\section{PENUTUP (KESIMPULAN)}

Berdasarkan atas pembahasan di atas dan dari rumusan masalah, maka dapat disimpulkan bahwa korupsi merupakan tingkah laku individu yang menggunakan wewenang dan kekuasaannya guna mengeruk keuntungan pribadi atau kelompok dan sangat merugikan kepentingan umum dan sangat bertentangan dengan normanorma yang berlaku. Bentuk-bentuk korupsi yang terjadi adalah penyelewengan dana-dana atau keuangan Negara sehingga dapat merugikan rakyat seperti skandal Bank Century, korupsi BNI dan BRI yang temasuk juga didalamnya Kementerian Agama serta korupsi-korupsi terjadi pada tingkat daerah yaitu provinsi, yang menyebabkan terjadinya korupsi adalah faktor kekayaan atau faktor motif pelaku yang mempunyai motif serakah dan tidak puas, serta lemahnya control Negara, perlakuan hukum yang berbeda, dan ringannya sanksi hukum. Dari berbagai kejadian korupsi tersebut maka tingkat korupsi di Negeri yang mayoritas penduduknya muslim ini termasuk Negara yang paling tinggi korupsinya di dunia. Meskipun berbagai macam upaya yang dilakukan oleh pemerintah namun, semua itu belum membuahkan hasil yang memuaskan. Padahal upaya pemberantasan korupsi ini dimulai sejak era Bung Karno sampai sekarang, tetapi seakan-akan korupsi ini bagaikan penyakit dan virus HIV/AID yang menyerang kekebalan tubuh manusia. Dalam hal ini adalah korupsi yang akan melemahkan pembangunan dan kesejahteraan rakyat. Pemberantasan korupsi dapat dilakukan secara tuntas menurut $\mathrm{H}$. Ismail Yusanto menyatakan bahwa terdapat enam langkah dalam pemberantasan korupsi yaitu; pertama: sistem penggajian yang layak; kedua: larangan menerima suap dan hadiah; ketiga: perhitungan kekayaan; keempat: teladan pemimpin; kelima: hukuman setimpal; keenam: Pengawasan masyarakat. Selain enam poin tersebut, pemberantasan korupsi harus melibatkan semua pilar masyarakat. Karena itu, korupsi akan lebih efektif diberantas bila pada tiga pilar tersebut dilakukan langkah-langkah yang terpadu. 
Pertama kita harus meyakini bahwa sebagian besar individu sebenarnya mempunyai sifat yang baik, karena Allah telah meniupkan sifat-sifat Agungnya semenjak dia berada di dalam rahim. Tentu saja dalam hal ini koruptor, itu merupakan pengaruh eksternal yang telah mengaburkan sifat-sifat baik tersebut. Yang paling utama disini adalah pembentukan tiga pilar yaitu pendidikan, lingkungan dan media. Tiga hal yang akan membangun suatu budaya. Untuk itu, agar tercipta budaya anti korupsi maka ketiga faktor eksternal tersebut harus dikondisikan agar masyarakat tidak berprilaku korupsi, yang akhirnya akan menjadi faktor-faktor pencegahan atau pemberantasan korupsi. Namun strategi individu dan Kultural terkadang masih belum cukup juga. Korupsi ada juga yang terjadi karena aturanaturan main yang salah. Untuk itu, harus dilakukan upaya-upaya merubah aturan yang dapat mencegah korupsi termasuk aturan memberantas korupsi setelah terjadi. Perhitungan kekayaan pejabat baik sebelum maupun setelah menjabat adalah satu ide yang baik. Kalau ada peningkatan yang tidak wajar dan tidak bisa dijelaskan, harta itu dapat disita untuk Negara atau yang bersangkutan dipidana.

Adapun saran yang dapat disampaikan didalam makalah ini adalah hendaknya pemerintah lebih meningkatkan kontrol terhadap lembaga-lembaga yang ada dan lebih menekankan sifat yang independen, kemudian ikut sertakan masyarakat untuk mengontrol jalannya pemerintahan, bisa diwakilkan dengan pembuatan kelompok atau organisasi yang sifatnya independen yang anggotanya berasal dari masyarakat, para aktivis dan mahasiswa. Hendaknya juga agar pemerintah melakukan penegakan hukum secara konsisten dan sesuai dengan tingkat pidana yang dilakukan oleh pelaku serta pemerintah juga harus berlaku secara independen tidak memihak siapapun dan tidak pandang bulu. Tidak hanya itu, pemerintah juga harus melihat kedepannya agar sifat-sifat korup ini tidak menurun ke anak cucu, maka bentuklah watak bangsa mulai dari sekarang menjadi mental yang baik dan bertanggung jawab dalam segala hal baik secara moral maupun kelakuan. Tentunya melalui pendidikan dan sikap keteladanan dari pada pemimpin yang menjadi tombak utama sebagai cerminan dari pemerintah terhadap generasi penerus. 


\section{DAFTAR PUSTAKA}

Alatas, Syed Hussein. 1986. Sosiologi Korupsi Sebuah Penjelajahan Dengan Data Kontemporer. Jakarta: LP3ES.

Azhari. 2004. Korupsi yang membumi. http:// www.hayatulislam.net

Bassar, M. Sudradjat. 1983. Hukum Pidana (Pelengkap KUHP), Bandung : CV Armico

Buletin Al Islam Edisi 182. Agar Memerangi Korupsi Tak Sebatas Jargon. Bayley, David H. 1995. "Bunga Rampai Korupsi”. Jakarta: LP3ES. Hehamahua, Abdullah dalam. 2004. "Membangun Sinergi Pendidikan dan Agama "

Dalam Gerakan Anti Korupsi”, Dalam Buku Dalam Buku Membangun Gerakan Anti Korupsi Dalam Perspektif Pendidikan, Yogyakarta: LP3 UMY, Partnership: Governance Reform In Indonesia, Koalisi Antar Umat Beragama Untuk Antikorupsi.

Harian REPUBLIKA, 21 Nopember 2003. Islam Dan Jalan Pemberantasan Korupsi. Harian Jurnal Bogor, Edisi 24 Juni 2009.

Muhammad, Rahmat kurnia. 2009. Pembuktian Terbalik Berbatas Korupsi.

http://www.mediaumat.com/cpntent/view/1050/65/

Saleh, K. Wantjik. 1983. Tindak Pidana Korupsi dan Suap, Jakarta : Ghalia Indonesia

Sjahrudin Rasul. Dkk. 2002. Upaya Pencegahan dan Penanggulangan Korupsi Pada Pengelolaan BUMN/BUMD dan Perbankan. Jakarta: Badan Pengawasan Keuangan Dan Pembangunan Tim Pengkajian SPKN 2002 